\title{
Teknik Sortir Produk Pangan menggunakan Teknik Bio-impedansi
}

\section{A SOFWAN F ALQAP1, JUNAS HAIDI ${ }^{2}$, ADHADI KURNIAWAN², SHINTIA VERONICA ${ }^{2}$, NURULIMAN SUPARDI ${ }^{1}$}

\author{
${ }^{1}$ Teknik Mesin Universitas Bengkulu, Indonesia \\ ${ }^{2}$ Teknik Elektro Universitas Bengkulu, Indonesia \\ Email: mao.moe@gmail.com, sofwan.alqap@unib.ac.id
}

Received 6 Desember 2020 | Revised 8 Februari 2021 | Accepted 22 Februari 2021

\begin{abstract}
ABSTRAK
Karakterisasi untuk memisahkan mutu-mutu yang berbeda dalam aplikasi industri dapat dipenuhi dengan menggunakan alat dengan kemampuan yang terbatas. Teknik sortir memanfaatkan sistem papan evaluasi Eval AD5933 EBZ berakurasi 0,5\% dilakukan terhadap pisang kepok (musa spp) hasil perkebunan di Pulau Enggano, Provinsi Bengkulu. Sistem dinyalakan dengan sambungan listrik bertegangan 2,7 V - 5,5 V mengeksitasi gelombang dari frekuensi $4000 \mathrm{~Hz}$ sampai 100.000 Hz kepada tiga sampel, masing-masing tiga kali sapuan. Tanpa ada modifikasi yang diberikan, sistem mampu membedakan impedansi musa spp antara jenis-jenis mutu mentah, mengkal dan masak melalui diagram Argand yang digambar dari data impedansi masing-masing. Diagram Argand yang dihasilkan menunjukkan jenis mutu masak dari musa spp lebih besar (dalam Ohm) dari jenisjenis mutu di bawahnya. Sistem ini dapat membantu industri pembuatan tepung pisang yang memerlukan pemilahan jenis bahan baku bermutu tertentu.
\end{abstract}

Kata kunci: sortir, mutu, buah pisang kepok, impedansi

\begin{abstract}
Characterization to sortir different qualities in industrial applications can be fulfilled by using a tool with limited capability. Sorting technique using a $0.5 \%$ accuracy Eval AD5933 EBZ evaluation board system has been carried out on kepok banana (musa spp) from the plantation of Enggano Island, Bengkulu province. The system powered by a $2.7 \mathrm{~V}-5.5 \mathrm{~V}$ DC low-voltage excited waves from $4000 \mathrm{~Hz}$ to $100,000 \mathrm{~Hz}$ frequencies to three samples, three sweeps of each. Without any modification, the system has been able to segregate different quality types of unripe, almost ripe and ripe from their Argand diagram drawn from their impedance data. The Argand diagram characterizes that the quality type of banana ripe is more expanded (in Ohm) than the other quality types of below. The system is applicable for a banana flour manufacturing industry that requires the sorting of certain types of quality raw materials.
\end{abstract}

Keywords: sorting, quality, musa banana, impedance 
Teknik Sortir Produk Pangan menggunakan Teknik Bio-impedansi

\section{PENDAHULUAN}

Teknik sortir dikenal sebagai cara yang dipakai dalam sebuah operasi memisahkan objek-objek kepada kelompok-kelompok menurut kriterianya masing-masing dengan mengevaluasi atau melakukan karakterisasi terhadap masing-masing objek terlebih dahulu. Keperluan alat untuk sortir mutu dalam aplikasi industri untuk objek tertentu seringkali dapat diselesaikan dengan menggunakan alat yang sederhana dan dengan kemampuan yang terbatas.

Dalam karakterisasi yang memanfaatkan sifat listrik, tahanan bahan (resistance) dan sifat kapasitan bahan (capacitance) adalah dua sifat yang berhubungan erat dengan sifat dasar material. Dua karakter yang saling berkaitan ini selalu diberikan secara unik dari material dalam kondisi-kondisi atau fasa-fasa yang berbeda. Kerapatan adalah rasio antara bagian ruang yang terisi dengan jumlah luas atau volume yang terisi dan tidak terisi dalam ruang dimaksud. Ruang tidak terisi tersebut, sering disebut membran, memiliki muatan dielectric senilai udara atau kehampaan (vacuum) yang dapat mengisinya. Nilai ini disebut juga dengan permittivitas. Dielektrik hampa (vacuum) bernilai 1 Farad per meter (F/m). Harga 1 dimaksudkan sebagai jumlah muatan listrik yang dapat dimuat sebesar satu kali. Semakin berkurang kehampaan nilai semakin besar. Dielektrik udara kering 1.0059. Konstanta dielektrik air 80. Ruang kosong memiliki konstanta dielektrik 8.85 x 10-12 F/m. Kapasitan dari sebuah sistem adalah produk dari konstanta dielektrik ruang kosong, konstanta dielektrik dari jenis bahan yang digunakan dan besar luas per tebal atau gap yang membentuknya. Kapasitan dipandang sebagai kemampuan menyimpan muatan. Kapasitan dapat dihitung sebagai produk beda potensial dan muatan.

Ruang terisi dimaksud di sini adalah bagian dimana kristalin mengambil ruang secara kontinyu. Meskipun kontinyu, tidak semua kristalin bersifat penghantar muatan listrik. Kuantitas muatan dalam sebuah sistem dinyatakan dalam Coulomb (C). Muatan sebuah elektron adalah $1.602 \mathrm{x}$ 10-19 C. Gerakan muatan elektron melalui media disebut sebagai arus, dinyatakan sebagai coulomb per satuan waktu. Coulomb per detik disebut sebagai ampere. Derajat kesulitan muatan menembus media disebut sebagai tahanan atau resistan.

Kristalin yang memiliki ikatan logam memiliki sifat menghantar listrik yang baik sehingga memiliki resistan kurang dari 0.1 ohm, dengan begitu sering dianggap sebagai memiliki nol resistan. Sedangkan kristalin bukan ikatan logam memilikinya yang lemah. Polimer memiliki resistan sangat tinggi, lebih besar dari 50 mega ohm, dengan begitu sering diabaikan dalam analisis sambungan listrik. Dua karakter yang berbeda secara berlawanan ini membuat resistan adalah resiprok dari konduktan pada suatu jenis bahan.

Pada material nyata resistan ( $\mathrm{R}$ ) dibedakan dari tahanan spesifik atau resistivitas (rho). Resistan dari sebuah bahan ditentukan oleh rasio panjang dan luas penampangnya. Dengan kata lain, resistan adalah jumlah muatan listrik yang dapat dialirkan per satuan panjang. Tentu saja ini juga akan berbeda dengan jenis bahan yang berbeda. Karena itu resistan adalah produk dari tahanan spesifik dari jenis bahan dan rasio panjang per luas penampang.

Kompleksitas dari model-model susunan sistem bahan, sifat resistan dan sistem kapasitan yang terbentuk memberi respon kepada sifat listrik yang berbeda. Sebuah informasi yang menyatakan dua informasi sekaligus, tahanan atau resistan $\mathrm{R}$ dan kapasitan $\mathrm{C}$, adalah impedansi Z. Hubungan impedansi $Z$ dengan arus I dan tegangan $V$ seperti hubungan resistan $\mathrm{R}$ dengan keduanya ( $\mathrm{I}$ dan $\mathrm{V}$ ), yaitu $\mathrm{Z}=\mathrm{V} / \mathrm{I}$, sementara pada sistem yang murni resistor berlaku $\mathrm{R}=\mathrm{V} / \mathrm{I}$. Kuantitas fisik impedansi diupayakan melalui karakterisasi percobaan. 
Material yang bebas kapasitan dan induktan di alam nyata itu tidak ada. Bahkan yang ideal keduanya perlu dipertimbangkan secara bersama-sama. Karena itu harga impedansi (Z) dimunculkan. Misal bahan dengan harga resistor (R) $106 \mathrm{ohm}$ dan memiliki kapasitor (C) $10^{-6}$ Farad, pada plot real-Z lawan imaginer-Z, dikenal dengan plot Nyquist, untuk sebuah resistor (R) akan diberikan harga imaginer-Z nol untuk semua harga real-Z yang ada, sementara plot Nyquist untuk kapasitor $(C)$ akan diberikan harga real-Z nol untuk semua harga imaginer-Z yang ada. Ketika keduanya, resistor dan kapasitor, dipadukan maka plot Nyquist akan memberi kurva setengah lingkaran di mana masing-masing harga berpasangan secara harmonis. Plot ini dikenal juga dengan diagram Argand. Fenomena keduanya memberi petunjuk tentang adanya informasi yang saling melengkapi untuk suatu obyek yang diamati. Karena resistan dan kapasitan dimiliki oleh semua sistem bahan, diharapkan model pendekatan ini dapat dipakai dalam aplikasi yang luas.

Dalam sistem material biologi (Alberts, dkk, 2015), badan terdiri atas banyak sistem organ. Organ tersusun dari tissue-tissue yang berbeda. Sebuah tissue terbentuk dari berbagai sel. Sebuah sel terbentuk dari senyawa-senyawa. Sel berjejaring disebut sellular. Bagian luar disebut Extra-Cellular Fluid (ECF) dan bagian dalamnya, Intra-Cellular Fluid (ICF), disebut protoplasma. Kedua sistem ini membentuk membran sel. Pada sistem tumbuhan, membran sel dibungkus lagi dengan dinding sel. Keadaan sistem dan perbedaan satu dengan yang lain membedakan respon mereka kepada listrik (Bera, dkk, 2016) (Grossi \& Ricco, 2017).

Bagian intra sellular dan ekstra sellular memiliki karakter resistan, tetapi ada bagian membran memberi karakter kapasitan (Damez, dkk, 2007) (Azzarello, dkk, 2012) (Ando, dkk, 2014). Keadaan ini melukiskan tissu biologi sebagai rangkaian listrik yang komplek (Damijan, dkk, 2006) (Bera' \& Nagaraju, 2009). Kompleksitas yang beragam sebagai fungsi dari komposisi, anatomi, dan kesehatan. Selain daripada itu juga oleh perbedaan parameter evaluasi yang digunakan seperti frekuensi yang diberikan pada evaluasi impedansi listrik (Arpaia, dkk, 2008) (Berra \& Nagarraju, 2011) (Santos, dkk, 2014) (Bouchaala, dkk, 2015). Tissue biologi sangat sensitif terhadap perubahan. Radang, infeksi dan penyakit memengaruhi sifat tissue. Karena itu setiap perubahan akan memberi respon listrik yang berbeda (Koziol, dkk, 2014) (Azevedo, dkk, 2016) (Chakraborty, dkk, 2015) (Ruiz, dkk, 2014).

Perubahan identitas biologi (Lelievre, dkk, 1997), misalnya dari mentah ke masak, terjadi karena ada perubahan biokimia akibat proses alami ataupun bukan alami dengan disertai beberapa perubahan fisiologi. Proses alami seperti buah masih di pohon (Burg \& Burg, 1965) (Hopkins \& Huner, 1995). Proses non alami dilakukan dengan melibatkan proses termal atau kimiawi (Herath, dkk, 1998) (Vasquez-Caicedo, dkk, 2007) (Golding, dkk, 1998).

Banyak jenis buah yang kaya mineral dan vitamin yang baik bagi kesehatan manusia. Pengujian mutu pada buah-buahan selain seringkali melibatkan metoda merusak, seperti metoda kimia dan biokimia (Hossain, dkk 2014), juga memerlukan keahlian dan memakan waktu. Karena itu model pengujian tanpa merusak diperlukan. Pengujian impedansi dilangsungkan dengan mengalirkan arus listrik pada frekuensi tertentu tanpa perlu merusak. Frekuensi berapa yang feasible atau cukup representatif untuk evaluasi benda biologi yang berbeda membuat evaluasi di rentang frekuensi yang lebar diperlukan. Mengingat karakter fisiologi benda biologi dipengaruhi oleh lingkungan di mana dia tumbuh.

Material biologi yang dijadikan sebagai objek penelitian metoda sortir adalah pisang kepok (Musa paradisiaca spp) asal pulau Enggano. Pulau ini terletak di Samudera Indonesia pada $05^{\circ} 31^{\prime} 13$ Lintang Selatan dan $102^{\circ} 16^{\prime} 00$ Bujur Timur. Kapal feri penyeberangan ke sana

$$
\text { ELKOMIKA - } 520
$$


memerlukan waktu tempuh paling cepat 12 jam dari Pelabuhan Laut Pulau Baai di Kota Bengkulu, meskipun keduanya berjarak $156 \mathrm{~km}$ atau 90 mil laut. Ia bagian dari Kabupaten Bengkulu Utara Provinsi Bengkulu. Dalam laporan yang ditulis tahun 1854 (Maryanto, dkk, 2017) pisang kepok Enggano sudah dipasarkan di Batavia (Jakarta sekarang). Diperkirakan per satu pekan pisang kepok yang diangkut dari Enggano ke Kota Bengkulu lebih dari 500 ton. Petani yang berkebun pisang kepok dapat meraih pendapatan sekitar sembilanbelas juta rupiah per hektar per tahun (Sinaga, Apri, \& Satria, 2019). Komoditi pisang kepok adalah hasil utama perkebunan rakyat Enggano diikuti dengan melinjo (Gnetum gnemon) dan kakao (Cacao).

Teknik sortir memisahkan satu jenis mutu kepada jenis mutu yang lain berdasarkan kepada perbedaan mutu-mutu dari objek yang dikarakterisasi (Vangelisti, dkk, 2017) (Li, dkk, 2014) (Gonzalez, 2019). Kemampuan karakterisasi ini diharapkan dapat membantu produsen tepung pisang untuk sortir bahan baku ketika mutu produk yang diinginkan ditentukan oleh parameter yang spesifik. Di sini dilaporkan alat yang murah yang dapat membedakan jenis pisang dalam tiga mutu yang berbeda. Faktor-faktor yang berpengaruh terhadap mutu menutup bagian diskusi dari laporan ini.

\section{METODE PENELITIAN}

\subsection{Impedansi}

Karakterisasi impedansi diperoleh dengan mengamati: plot magnitude-Z lawan frekuensi, plot fasa-Z lawan frekuensi, dan plot imaginer-Z lawan real-Z. Tetapi plot ketiga biasa dipakai dalam melaporkan evaluasi impedansi biologi. Karakter atau plot ini diperoleh dari mengalirkan arus listrik dengan besar tegangan tertentu pada lebar daerah frekuensi tertentu. Magnitude$Z$ dan fasa $(\theta)$ berhubungan dengan resistan $(R)$ dan reaktan $(X)$, masing-masing sebagai fungsi dari frekuensi f, ditunjukkan pada Persamaan (1) dan (2).

$$
\begin{aligned}
& Z(f)=R(f)-j X(f) \\
& \theta(f)=-\tan ^{-1}\left(\frac{X}{R}\right)
\end{aligned}
$$

Di mana $\mathrm{j}$ adalah bilangan komplek $\sqrt{ }(-1)$. Dalam kasus bahan yang bersifat magnet, bagian reaktan di sebelah kanan, yaitu $X$, terdiri dari unsur induktif $\mathrm{XL}$ dan kapasitif $\mathrm{XC}$. Yaitu $\left(+j \mathrm{X}_{\mathrm{L}}-\right.$ $j X_{c}$ ). Pada kasus material biologi pada frekuensi rendah unsur induktif amat sangat kecil, atau diabaikan (Bera, dkk, 2016) (Maxwell, 1892) (Lasia, 2014). Hubungan induktif $X_{L}$ dengan induktan $L$ dan kapasitif $X_{C}$ dengan kapasitan $C$ ditentukan dari definisi $X_{L}=2 \pi f L$ dan $X_{C}=1 /(2 \pi f C)$, atau $X_{L}=\omega L$ dan $X_{C}=1 /(\omega C)$, di mana $\omega=2 \pi f$.

Harga $R(f)$ dan $X(f)$ dari impedansi Z(f) dapat dihitung secara langsung dengan Persamaan (3) dan (4).

$$
\begin{aligned}
& R(f)=|Z(f)| \cos (\theta(f)) \\
& X(f)=|Z(f)| \sin (\theta(f))
\end{aligned}
$$

Teori hukum Ohm tegangan bolak-balik menyatakan impedansi $Z(f)$ adalah fungsi transfer yang dapat dihitung dari tegangan $V(f)$ dibagi arus yang masuk $I(f)$.

Plot jenis ketiga, yaitu imaginer-Z lawan real-Z, membentuk diagram setengah lingkaran, atau dikenal diagram Argand. Hubungannya dengan model rangkaian listrik paralel ekivalen dijelaskan pada Gambar 1. Penjelasan tentang diagram dan model masing-masing yang 
berbeda dijelaskan di bawah keterangan gambar. Bentuk setengah lingkaran tersebut memiliki pusat di sekitar sumbu ordinat. Besar dan kecil dari harga jari-jarinya berhubungan dengan besar dan kecil harga impedansi listrik dari obyek. Dalam karakterisasi, analisis terkadang dihadapkan kepada fenomena diagram Argand yang terbuka. Ini disebabkan kehadiran impedansi Warburg (Lasia, 2014), yaitu besaran di luar harga resistan dan reaktan dari obyek yang dievaluasi.

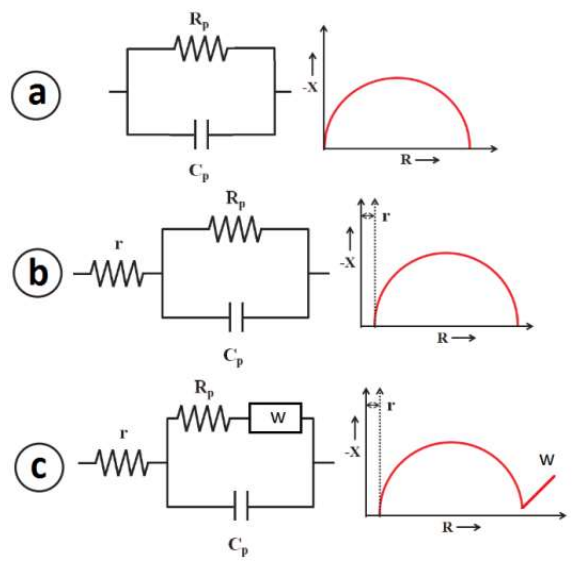

\section{Gambar 1. Model Rangkaian Elemen Listrik Paralel dan Grafik Setengah Lingkaran Diagram Argand untuk Plot Bagian Imaginer(-X) Lawan Bagian Real(R) (Uygun \& Ertuğrul Uygun, 2014)}

Diagram Argand memiliki titik potong antara garis absis dan ordinat pada nilai 0 (nol) ohm. Gambar 1 (a): model rangkaian paralel murni, di mana RP adalah unsur resistan dan CP adalah unsur kapasitan yang keduanya terpasang secara paralel, RP || CP. Bagian sebelah kiri dari diagram Argand merapat ke harga 0 ohm. Gambar 1(b): model rangkaian paralel (RP || CP) yang berhubungan seri dengan $r$, yaitu harga resistan kontribusi dari sistem alat ukur. Dengan ada kontribusi ini, diagram Argand digeser sejauh $r$ dari titik nol ohm ke arah kanan R. Gambar 1 (c): model rangkaian seri antara RP dan W (RP-W), keduanya berhubungan paralel dengan $\mathrm{CP}(\mathrm{RP}-\mathrm{W} \| \mathrm{CP})$, beserta kontribusi $r$ adalah dari alat ukur, sedangkan $\mathrm{W}$ adalah impedansi Warburg sebagai kontribusi dari ketidakmurnian dalam sistem obyek yang dievaluasi.

\subsection{Perangkat}

Perangkat percobaan terdiri dari tiga unsur utama (lihat Gambar 2): papan evaluasi - objek evaluasi - PC (komputer). Papan evaluasi Eval AD5933 EBZ dari Analog Devices Inc. tersedia di pasar lengkap dengan software. Penjelasan lengkap dari sistem ini dapat diakses dari web pembuat (Analog Devices Inc, 2015). Sistem sedia dikalibrasi dengan resistor dan kapasitor yang sesuai. Catu daya disediakan melalui USB disambungkan ke PC. Objek evaluasi, yaitu pisang kepok, dihubungkan ke papan evaluasi melalui dua kabel dan dua dispossable electrode. Data hasil evaluasi, yaitu frequency, impedance, phase, real, imaginer, dan magnitude per satu kali percobaan disediakan oleh sistem dalam folderAD5933 dalam file csv yang siap olah di aplikasi pengolah spreadsheet. 


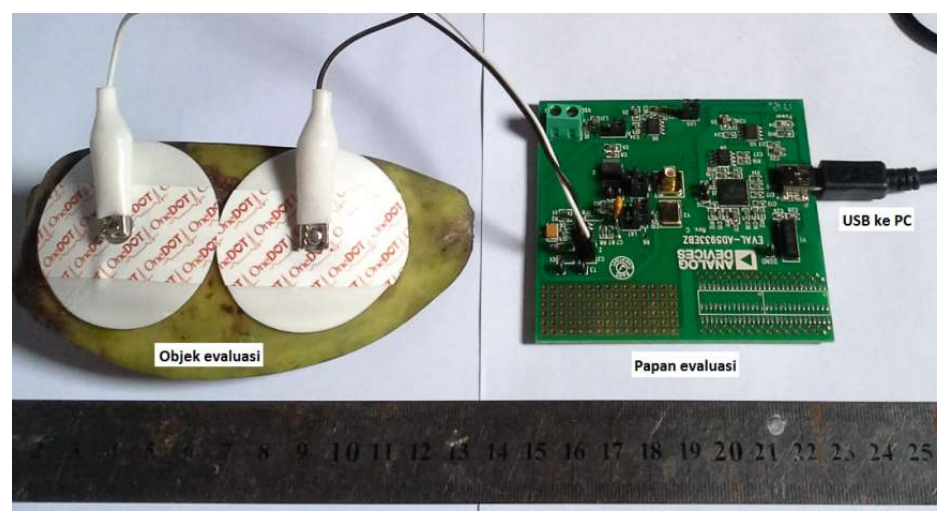

\section{Gambar 2. Percobaan Melibatkan Papan Evaluasi, Objek Evaluasi} dan PC (Komputer) di Ujung USB
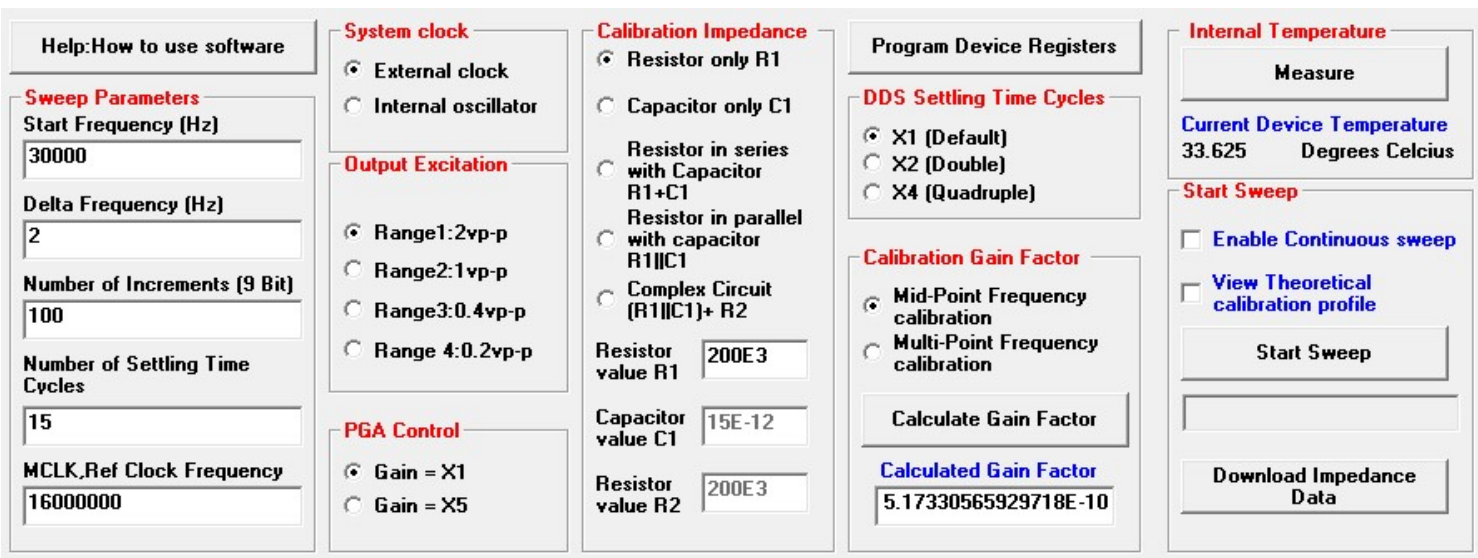

Gambar 3. Panel Interaktif untuk Pengaturan Eval AD5933 EBZ

Fitur dan fungsi utama. Di sini dua kelompok fitur dan fungsi akan dijelaskan, yang terkait dengan sistem perangkat keras pada papan evaluasi (Gambar 2) dan yang terdapat pada panel interaktif dari perangkat lunak (Gambar 3). Perangkas keras AD5933 memuat elemen-elemen utama: MCLK, DDS, DAC/ADC, LPF, register, I ${ }^{2} \mathrm{C}$, DFT dan sensor temperatur. Gambar rangkaian perangkat keras dijelaskan dengan rinci pada situs pembuat.

MCLK atau maximum clock adalah elemen jam sistem yang menghasilkan pulsa-pulsa. Ia berupa osilator kuarsa, dipilih dengan signal timing yang tinggi, sehingga ketika dikenai aliran listrik dia bergetar dengan kecepatan di atas waktu terlama yang diperlukan agar setiap sinyal dapat disebarkan ke seluruh sirkuit untuk menyinkronkan semua komponen di papan. Sistem ini mencegah sinyal datang sebelum sinyal lain siap, dengan demikian semuanya dijaga tersinkronisasi. Kapasitas frekuensi bawaan sebesar $16.766 \mathrm{MHz}$, atau ditulis di default 16.000.000. PLF atau low pass filter digunakan untuk memperoleh hasil yang bersih dari fluktuasi rentang pendek, atau noise, dan menyisakan fluktuasi rentang panjang. PLF jenis aktif dipilih dengan memberi penguat operational amplifier (op amp) dan Gain, untuk menentukan batasan respon frekuensi maksimum.

Pulsa-pulsa dari MCLK diterima, dikumpulkan dan diolah menjadi peta digital gelombang sinus di DDS (direct digital synthesizer) 27 bit. Selanjutnya sampel sinus digubah dari digital ke analog atau sebaliknya di DAC/ADC (digital - analog conventer) 12 bit, lalu diolah di LPF. Luarannya diperkuat dengan Gain. Impedansi untuk setiap titik frekuensi dihitung pada DFT 
Alqap, dkk

(discrete Fourier transform) setelah digandakan sebanyak 1024 sampel per satu titik frekuensi. Hasilnya disimpan dalam 2 buah register masing-masing 16 bit untuk Rea/dan Imaginer. Dua register ini disambungkan dengan inter-integrated circuit $\left(\mathrm{I}^{2} \mathrm{C}\right)$ sebagai interface ke microcontroller. Bagian-bagian dari panel interaktif pada sistem perangkat lunak dijelaskan berikut ini.

Sweep parameter. Sebelum mengeksekusi sistem, ada tiga parameter sweep (sapu) yang diperlukan untuk diberikan. Yaitu Start Frequency $(\mathrm{Hz})$, Delta Frequency $(\mathrm{Hz})$ dan Number of Increment. Jika tertulis 30000 pada Start Frequency, 2 pada Delta of Increment dan 100 pada Number of Increment, maka proses sweep akan mengalirkan gelombang listrik secara bertahap dari frekuensi $30.000 \mathrm{~Hz}$ sebagai Start Frequency (frequensi mula), lalu 30.002, $30.004, \ldots, 30.100,30.102, \ldots$, sampai 30.200, sehingga ada 101 data frekuensi yang disapukan, dan berhenti pada 30.200 sebagai Stop Frequency (frekuensi akhir). Yakni Stop Frequency $=$ Start Frequency + (Delta Frequency $x$ Number of Increment). Number of increment dibatasi sampai 511. Jika sistem ingin dipakai pada rentang frekuensi dari $50 \mathrm{~Hz}$ sampai $2 \mathrm{MHz}$, yaitu daerah evaluasi banyak peneliti melakukan sweep untuk obyek biologi (Chowdury, Bera, Ghoshal, \& Chakraborty, 2017), maka diberi 50 di Start Frequency, 500 di Number of Increment dan 4000 di Delta of Increment. Begitu harapan. Tetapi kemampuan sistem hanya sampai di bawah $500 \mathrm{kHz}$ atau $500.000 \mathrm{~Hz}$, sehingga hanya bisa dipasang di Start Frequency, Delta of Increment dan Number of Increment sebagai 50, 800, 500 secara berurutan.

Ketika nilai-nilai sudah diberikan untuk frekuensi mula, delta frekuensi dan banyak kenaikan yang diregister, berikutnya adalah kegiatan mengkalibrasi AD5933 dengan menyediakan impedansi yang diketahui (Zknown) yang sekiranya terletak di titik tengah kisaran impedansi yang tidak diketahui (Zunknown). Impedansi kalibrasi yang diketahui memberi besar kode digital pada titik frekuensi kalibrasi. Kedua data ini digunakan untuk kalibrasi. Besaran kode digital yang diberikan setelah setiap sapuan frekuensi kemudian dikalikan dengan faktor penguatan (Gain Factor) untuk menghasilkan nilai Admittance. Impedance adalah kebalikan dari nilai admitansi ini.

Output Exitation. Bagian ini, misal dipilih range 1: 2Vp-p dengan PGA control: Gain X1, menunjukkan bahwa impedansi kalibrasi (Zknown) dan impedansi yang tidak diketahui (Zunknown) sesudahnya akan dieksitasi dengan sinusoid $2 \mathrm{Vp}-\mathrm{p}$ dan akan diperoleh nilai $\mathrm{x} 1$ sebelum diambil sampelnya oleh ADC. Nilai tegangan eksitasi keluaran dan Gain PGA (programmable Gain amplifier, penguat Gain yang terprogram) dipilih sampai rentang dinamis optimal ditampilkan ke depan dan ke ADC tanpa menjenuhkan saluran masukan ADC. Gain di sekitar penguat trans impedansi diberikan oleh RFB / Zunknown. Di mana RFB adalah nilai resistansi feedback yang diketahui nilainya, dan Zunknown adalah impedansi yang diuji.

Setelah tiga nilai parameter sweep dipasang dan kondisi kalibrasi sistem yang optimal dipilih, kemudian tombol "Program Device Register" ditekan untuk mengirimkan data input dan memprogram AD5933. Dengan nilai impedansi kalibrasi dimasukkan, Gain Factorakan dihitung oleh PC setelah tombol "Calculated Gain Factor" ditekan. Gain Factor digunakan untuk sweep berikutnya ketika pengguna menekan tombol "Start Sweep". Jika profil kalibrasi impedansi teoritik dari topologi kalibrasi yang dipilih ingin dilihat, maka centang kotak "view theoritical impedance profile" sebelum menekan tombol "Start Sweep". Kedua profil dibedakan antara garis kalibrasi yang terukur (garis hitam) dan yang ideal (biru). Jika hasil kalibrasi dianggap cukup, maka ganti impedansi kalibrasi dengan impedansi yang ingin diketahui (Zunknown), hapus centang "view theoritical impedance profile" dan tekan kembali "Start Sweep", setelahnya profil impedansi Zunknown yang diukur akan ditampilkan. Profil impedansi (Impedansi absolut |Z|) untuk kalibrasi (Zknown) atau impedansi yang diukur (Zunknown)

$$
\text { ELKOMIKA - } 524
$$


Teknik Sortir Produk Pangan menggunakan Teknik Bio-impedansi

ditampilkan di panel depan pada tab "Impedansi |Z|". Untuk menampilkan profil Impedansi Fasa $(\theta)$ yang diukur, aktifkan tab "Fase Impedance". Data impedansi absolut $|Z|$ dan fasa $\theta$ yang diukur dapat dikeluarkan dengan menekan tombol "Download Data". Data tersebut siap disimpan ke dalam file berekstensi csv.

Menghitung Magnitude Impedansi. Tahap pertama dalam menghitung impedansi untuk setiap titik frekuensi adalah menghitung magnitude DFT (discrete Fourier transform) pada titik tersebut. Algoritma DFT dibuat untuk memberikan sebuah data real(R) dan imaginer(I) pada setiap frekuensi luaran selama proses sweep berlangsung. Yaitu dengan $X(f)=$ $\left.\sum_{n=0}^{1023}(x(n) \cos n-J \sin (n))\right)$ di mana $\mathrm{X}(\mathrm{f})$ adalah power pada sinyal di titik frekuensi $\mathrm{f}, \mathrm{x}(\mathrm{n})$ adalah luaran $\mathrm{ADC}, \cos (\mathrm{n})$ dan $\sin (\mathrm{n})$ adalah vektor tes sampel yang diberikan DDS pada titik frekuensi f. Penggandaan diakumulasikan per 1024 sampel per satu titik frekuensi. Hasilnya disimpan dalam 2 kali rekaman atau register 16 bit masing-masing untuk real dan imaginer. Magnitude dihitung sebagai $\sqrt{ }\left(\mathrm{R}^{2}+\mathrm{I}^{2}\right)$ sedangkan fasa sebagai $\tan ^{-1}(\mathrm{I} / \mathrm{R})$. Contoh register data Real sebesar 907 desimal dan register data Imaginer sebesar 516 decimal maka Magnitude $=\sqrt{ }\left(907^{2}+516^{2}\right)=1043.506$. Untuk mengubah ini ke impedansi maka perlu dikalikan faktor skala yang disebut Gain Factor. Gain factor dihitung ketika sistem dikalibrasi dengan impedansi yang diketahui (Zknown) dipasang di pin-pin VOUT dan VIN.

Contoh. Output Excitation dipilih Range 1: 2 Vp-p, PGA Contro/ dipilih Gain $=x 1$, Calibration Impedance dipilih Resistor only R1, Resistor value R1 diisikan 200E3 atau 200000 (200 k 2 ), yang lain dibiarkan apa adanya. Ditekan tombol "Program Device Registers". Lalu ditekan "Calculate Gain Factor". Maka pada frekuensi kalibrasi $30 \mathrm{kHz}$ akan diberi register data Real $(\mathrm{R})=-3996$ desimal, register data Imaginer $(\mathrm{I})=+8830$ desimal, Magnitude dihitung dengan rumus $\sqrt{ }\left((-3996)^{2}+8830^{2}\right)=9692.106$. Maka Gain Factor dihitung dengan Gain Factor $=$ Admittance/Magnitude $=((1 /$ Impedance $) /$ Magnitude $)=200 \mathrm{k} \Omega / 9692.106=515.819 \times 10^{-12}$. Untuk menghitung Impedansi, rumus ini diubah menjadi Impedance $=1 /$ (Gain Factor $\mathrm{x}$ Magnitude). Register kalibrasi $200 \mathrm{k} \Omega$ pada frekuensi $30 \mathrm{kHz}$ tersebut sudah memberikan harga Gain Factor, harga ini akan digunakan untuk pengukuran impedansi yang ingin diukur (yakni Zunknwon). Misal Zunknown itu adalah $510 \mathrm{k} \Omega$ maka pengukurannya pada frekuensi $30 \mathrm{kHz}$ akan dihitung sebagai Impedansi $=1 /\left(515.819 \times 10^{-12} \times\right.$ Magnitude $)$. Magnitude ini akan diberikan ketika obyek evaluasi dipasang dan tombol Start Sweep ditekan. Nilai Impedansi yang diberikan mesti ada error, untuk memperkecil error ini opsi Calibration Gain Factordiberikan, apakah menggunakan nilai tengah, opsi Mid-Point Frequency calibration, atau menggunakan nilai rata-rata, opsi Multi-Point Frequency calibration.

Opsi kalibrasi nilai tengah. Misal frekuensi pengukuran dari $55 \mathrm{kHz}\left(\mathrm{f}_{1}\right)$ sampai $65 \mathrm{kHz}\left(\mathrm{f}_{2}\right)$. Gain Factor yang dihitung pada $55 \mathrm{kHz}$ adalah $1.031224 \times 10^{-9}$ dan pada $65 \mathrm{kHz}$ adalah $1.035682 \times 10^{-9}$. Maka selisih dari dua Gain Factor ini $\left(\Delta \mathrm{GF}=\mathrm{GF}\left(\mathrm{f}_{2}\right)-\mathrm{GF}\left(\mathrm{f}_{1}\right)\right)$ adalah 4.458000 $x 10^{-12}$ dari selisih frekuensi bawah dan atas, atau lebar frekuensi $\left(\Delta f=f_{2}-f_{1}\right)$, sebesar 10 $\mathrm{kHz}$. Bila Gain Factor (GF) pada poin frekuensi tertentu (fp) ingin dihitung maka dihitung dengan model ektrapolasi, yaitu $\mathrm{GF}(\mathrm{fp})=\Delta \mathrm{GF} \bullet\left(\mathrm{fp}-\mathrm{f}_{1}\right) / \Delta \mathrm{f}+\mathrm{GF}\left(\mathrm{f}_{1}\right)$. Jika fp itu pada $60 \mathrm{kHz}$ maka GF pada $60 \mathrm{kHz}$ adalah $=4.458000 \times 10^{-12} \times 5 / 10+1.031224 \times 10^{-9}=1.033453 \times$ $10^{-9}$.

PGA Control. Apakah memilih $x 1$ atau $x 5$ akan menentukan Gain voltase, cara menentukannya adalah dengan rumus = Resistor Kalibrasi / Zunknown x PGA Gain. Jika diambil $200 \mathrm{k} \Omega$ sebagai kalibrasi dan PGA Gain dipilih x1 berarti ini untuk Zunknown berharga di sekitar $200 \mathrm{k} \Omega$ agar ADC input $2 \mathrm{~V}$ p-p (Range 1 ) dapat menerimanya. Bila dipilih $\times 5$, voltase yang dikirim akan membuat jenuh ADC, sehingga sistem terganggu. 
Pengukuran Fasa Impedansi. Pengukuran fasa impedansi (Z $\theta)$ ada dua tahap. Tahap pertama melibatkan AD5933 menghitung fasa sistem dari resistor kalibrasi ( $\theta$ known) yang dipasang pada pin-pin VOUT dan VIN. Dengan resistor dipasang tidak ada fasa yang maju (lead) atau tertinggal (lag) yang ditambahkan kepada sinyal AD5933. Fasa yang dihasilkan murni akibat kutub-kutub internal dari AD5933. Ini fasa internal sistem, Zsistem.

Pada tahap kedua, ketika obyek yang ingin diketahui ( $\theta$ unknown) dipasang, misal sebuah kapasitor dipasang pada pin-pin VIN dan VOUT, dan sistem dieksekusi, maka dihitung fasa impedansi $(Z \theta)=$ Ounknown - Zsistem. Contoh. Pasang sebuah resistor $220 \mathrm{k} \Omega$ (resistor feedback) di RFB, pilih PGA x1, lakukan eksekusi sistem. Kemudian pasang kapasitor 10pF, lakukan eksekusi. Plot fasa sistem (dalam derajat) lawan frekuensi untuk kedua obyek: resistor dan kapasitor. Lalu plot $Z \theta=\theta$ unknown - Zsistem (dalam derajat).

Yang perlu diperhatikan untuk menghitung fasa adalah fungsi arctangen yang hanya bekerja pada angka positif, yakni baik Real dan Imaginer keduanya positif, atau pada kuadran pertama. jika Rea/ positif dan Imaginer negatif data berada pada kuadran kedua, ketika ini arctangen memberi sudut negatif, karena itu perlu ditambah 180 derajat agar arctangen memberi harga yang benar. Begitu juga ketika keduanya berharga negatif, yakni di kuadran ketiga, arctangen akan memberi harga positif, maka perlu ditambah 180 derajat agar memberi harga yang benar. Ketika bagian Real positif dan bagian Imaginer negatif, yakni di kuadran keempat, arctangen memberi harga negatif, maka perlu ditambah 360 derajat untuk mendapat harga fasa yang benar.

Jika magnitude impedansi $|\mathrm{Z}|$ dan fasa impedansi $\mathrm{Z} \theta$ (dalam radian) sudah betul dihitung, maka dimungkinkan untuk menghitung magnitude resistif (Rea) dan magnitude reaktif (Imaginer) kepada impedansi obyek yang ingin diketahui (Zunknown) menggunakan proyeksi vektor magnitude impedansi kepada bagian Real dan Imaginer dengan Persamaan (5) dan (6).

$$
\begin{aligned}
& \mid \mathrm{Z} \text { Real }|=| \mathrm{Z} \mid \mathrm{x} \cos \mathrm{Z} \theta \\
& \mid \mathrm{Z} \text { Imaginer }|=| \mathrm{Z} \mid \mathrm{x} \sin \mathrm{Z} \theta
\end{aligned}
$$

\subsection{Prosedur Percobaan}

Prosedur pengoperasian papan evaluasi Eval AD5933 EBZ adalah menurut urutan sebagai berikut: (1) Koneksi Papan ke PC melalui kabel USB, (2) Koneksi dua kabel (VIN, VOUT) ke dua sisi RFB untuk memasang kalibrasi Zknown, (3) Koneksi dua kabel (VIN, VOUT) ke dua sisi Z untuk memasang kalibrasi Zunknown, (4) Aktifkan PC, (5) Aktifkan software AD5933 Eval, (6) Isi Sweep Parameter, (7) Pilih dan isi kalibrasi ZKnown yang sesuai, (8) Opsi A untuk kalibrasi dan Opsi B untuk pengukuran. Pasang Zknown di kabel RFB (Opsi A) dan/atau pasang ZUnknown di Z (Opsi B) (9) Klik Register, (10) Klik Calculate Gain Factor, (11) Klik Measure temperature, (12) Klik Enable continous sweap (jika data luaran diinginkan), (13) Klik Start Sweap, (14) Tunggu sistem mengeksekusi hingga selesai. Klik Download Data. File csv tersedia di folder AD5933.

Prosedur pengolahan data untuk tujuan sortir mutu dilakukan kepada tiga tahap. Pertama, file csv dibuka dalam pengolah spreadsheet, lalu data pada kolom Frequency, kolom Real, dan kolom Imaginary dipisahkan. Kedua, pengujian Standar Deviasi (SD) untuk melihat apakah percobaan yang dijalankan memberi data yang valid. Bagian ini dijelaskan dalam diskusi. Ketiga, pengolahan grafik untuk membat diagram Argand. Kunci keberhasilan percobaan ditentukan oleh tiga aspek: aspek parameter, aspek koneksi, dan aspek fisik objek evaluasi. Aspek parameter yaitu pada pemilihan kalibrasi dan pemilihan rentang frekuensi yang tepat

$$
\text { ELKOMIKA - } 526
$$


ukur bagi benda yang menjadi objek evaluasi. Pada percobaan ini digunakan kalibrasi resistor $3000 \mathrm{Ohm}$ dan rentang frekuensi dari $4000 \mathrm{~Hz}$ sampai $100.000 \mathrm{~Hz}$. Aspek koneksi tertentu pada koneksi kabel ke pin-pin pada papan evaluasi dan cekaman dispossable electrode pada objek evaluasi. Aspek fisik objek evaluasi terkait dengan keadaan fisik, baik pada permukaan kulit pisang (datar/ tidak datar) maupun pada kondisi di bawah kulit (utuh/ busuk).

\section{HASIL DAN DISKUSI}

Pisang kepok Enggano dalam tiga jenis mutu yang berbeda, yaitu: mentah, mengkal dan masak $\left(\mathrm{P}^{\mathrm{a}}, \mathrm{P}^{\mathrm{b}}\right.$, dan $\mathrm{P}^{\mathrm{c}}$ ) dijadikan obyek evaluasi dari percobaan Eval AD5933 EBZ. Untuk satu obyek mutu diambil tiga buah pisang dari kelompoknya (sisir atau sikat). Ketiga kriteria dipilih menurut warna kulit pisang-pisang yang dominan dalam satu sikat. Tiga pisang mentah diambil dari satu sikat pisang kepok dengan warna kulit yang semuanya hijau cerah. Tiga pisang mengkal diambil dari yang semua kulitnya berwarna hijau tua, dengan ada kesan warna kuning akan muncul. Tiga pisang masak diambil dari yang semua kulitnya berwarna kemerahan, warna merah lebih dominan dari warna kuning. Masing-masing dilakukan percobaan tiga kali $\left(\mathrm{P}_{1}^{\mathrm{a}}, \mathrm{P}_{2}^{\mathrm{a}}\right.$, dan $\mathrm{P}_{3}^{\mathrm{a}}$, begitu juga dengan $\mathrm{P}^{\mathrm{b}}$ dan $\left.\mathrm{P}^{\mathrm{c}}\right)$. Harga rata-rata dari tiga data $\left(\mathrm{P}_{\mathrm{rt}}^{\mathrm{a}}, \mathrm{P}_{\mathrm{rt}}^{\mathrm{b}}\right.$, dan $\mathrm{P}_{\mathrm{rt}}^{\mathrm{c}}$ ) untuk masing-masing Real dan Imaginary diplot menjadi diagram Argand (lihat Gambar 4). Dari tangga $4000 \mathrm{~Hz}$ ke tangga $100.000 \mathrm{~Hz}$ diperoleh 500 buah data per satu kali percobaan untuk masing-masing $\mathrm{P}^{\mathrm{a}}, \mathrm{P}^{\mathrm{b}}$, dan $\mathrm{P}^{\mathrm{c}}$ (misal $\left.\mathrm{P}_{1,1-500}^{\mathrm{a}}\right)$. Validasi statistik dilakukan dengan menghitung standar deviasi (SD) per tangga frekuensi dari tiga kali percobaan per satu buah pisang, sehingga didapat $\mathrm{SD}$ dari $\mathrm{P}_{1,1}^{\mathrm{a}}, \mathrm{P}_{2,1}^{\mathrm{a}}$, dan $\mathrm{P}_{3,1}^{\mathrm{a}}$, SD dari $\mathrm{P}_{1,2}^{\mathrm{a}}, \mathrm{P}_{2,2}^{\mathrm{a}}$, dan $\mathrm{P}_{3,2}^{\mathrm{a}}$, begitu seterusnya sampai SD dari $\mathrm{P}_{1,500}^{\mathrm{a}}, \mathrm{P}_{2,500}^{\mathrm{a}}$, dan $\mathrm{P}_{3,500}^{\mathrm{a}}$, kemudian nilai SD rata-rata dihitung. Nilai SD rata-rata yang didapat antara 3 dan 10 menunjukkan bahwa sistem ini cukup akurat. Sesuai dengan pernyataan dari pembuat bahwa alatnya memiliki tingkat akurasi 0,5\%. Apabila SD rata-rata yang diberikan bernilai puluhan atau bahkan ratusan berarti ada masalah dalam sistem sambungan atau pisang sudah rusak atau busuk. Visualisasi diagram Argand hasil sweep parameter dari $4000 \mathrm{~Hz}$ sampai $100.000 \mathrm{~Hz}$ dengan kenaikan frekuensi sebanyak 500 kali telah berhasil membedakan tiga jenis mutu yang berbeda dari kelompok-kelompok pisang kepok sebagaimana ditunjukkan pada Gambar 4.

Analisis Local Operating Model (LOM) terhadap data luaran evaluasi pisang kepok digunakan aplikasi Electrochemical Impedance System milik Bondanrenko dan Ragoisha (Bondarenko \& Ragoisha, 2005) berdasarkan model dari Vladikova dan Stanov (Vladikova \& Stoynov, 2004). Hasilnya menunjukkan bahwa data sesuai dengan model di Gambar 1.

Pola diagram Argand berubah dari impedansi reaktan yang rendah pada jenis mutu pisang mentah kepada impedansi reaktan yang tinggi pada jenis mutu pisang masak. Perbedaan ini mungkin terkait dengan kadar glukosa, percobaan AboBakr et al (AboBakr, dkk, 2019) menunjukkan bahwa semakin banyak kadar glukosa yang diberikan akan semakin besar harga impedansi. Faktor lain yang mungkin berpengaruh terhadap perubahan impedansi adalah kadar air. Kertesz et al (Kertesz, dkk, 2015) menguji pada wortel dan Islam et al (Islam, dkk, 2015) pada bawang, dengan semakin berkurang kadar air semakin besar impedansi. Tetapi tidak demikian halnya pada pisang. Jenis mutu pisang yang lewat masak akan mengeluarkan cairan dalam penyimpanan. Selain pengaruh kandungan air, pengaruh mineral yang dikandung juga meningkat pada pisang musa spp dari jenis mutu mentah kepada jenis mutu masak (Adeyemi \& Oladiji, 2009). 


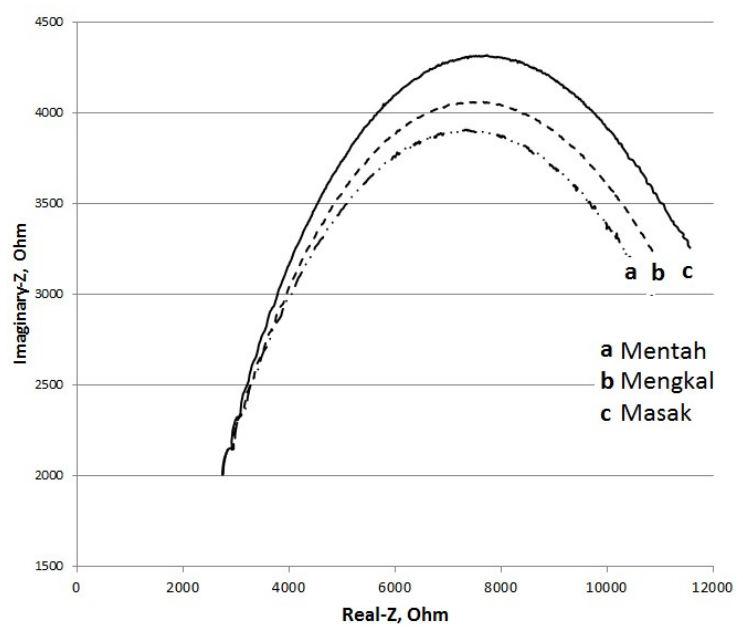

Gambar 4. Analisis Bioimpedansi pada Tiga Jenis Mutu Pisang yang Berbeda

Pada perusahaan dengan area bisnis dengan produk tertentu, karakter produk akan menjadi lebih spesifik, memerlukan rentang area evaluasi yang terbatas dan memberikan karakter model yang khas. Oleh karena itu, alat yang digunakan untuk sortir tidak perlu memiliki rentang kemampuan yang lebar. Untuk keperluan yang terbatas, alat yang murah tersedia dengan tingkat akurasi yang memadai.

\section{KESIMPULAN}

Karakterisasi sortir produk untuk memisahkan satu jenis mutu dari jenis mutu yang berbeda telah berhasil dilakukan menggunakan papan evaluasi Eval AD5933 EBZ. Dibandingkan dengan LCR-meter komersial yang biasanya memiliki keterbatasan pada rentang frekuensi yang disediakan, tidak menyediakan opsi model-model ekivalen sirkuit RC untuk sel, dan meminta harga tambahan untuk perangkat lunak pengolah data, Eval AD5933 EBZ tidak hanya murah melainkan sudah menyediakan item-item yang tidak ditawarkan oleh LCR- meter sehingga sistem ini sedia dikembangkan sebagai alat bantu pada bagian pengujian mutu terkait objek biologi. Bila sistem yang ada diterima apa adanya, tanpa dilakukan modifikasi, keterbatasan alat dalam bidang aplikasi dapat diatasi dengan mencermati karakteristik nilai standar deviasi. Pola diagram Argand berkembang atau menyusut seiring dengan perbedaan jenis-jenis mutu pisang kepok di atas sesuai dengan laporan penelitian lain pada buah pisang pada umumnya. Penelitian ini berhasil memanfaatkan sistem sedia jadi Eval AD5933 EBZ untuk teknik sortasi antara tiga jenis mutu pisang kepok, yaitu mentah, mengkal dan matang. Analisis dari standar deviasi terhadap data yang diberikan dapat menjelaskan kebaikan fisik buah dan koneksi wiring.

\section{UCAPAN TERIMA KASIH}

Pembiayaan kegiatan penelitian bersumber dari dana Hibah Penelitian Unggulan Universitas di bawah pengaturan Lembaga Penelitian dan Pengabdian Masyarakat (LPPM) Universitas Bengkulu tahun 2020. Kegiatan penelitian sangat tertolong oleh kerja rekan-rekan Fadiyah Nahdah Abrar dan Kiang Santan di Laboratorium Elektronika dan Telekomunikasi Fakultas Teknik Universitas Bengkulu. 


\section{DAFTAR RUJUKAN}

AboBakr, A., Mohsen, M., Said, L. A., Madian, A. H., Elwakil, A. S., \& Radwan, A. G. (2019). Banana Ripening and Corresponding Variations in Bio-Impedance and Glucose Levels. Proceedings of Novel Intelligent and Leading Emerging Sciences Conference, (pp. 130 133). Giza, Egypt: IEEE.

Adeyemi, O. S., \& Oladiji, A. T. (2009). Compositional Changes in Banana (Musa ssp.) Fruits During Ripening. African Journal of Biotechnology, 8(5), 858 - 859.

Alberts, B., Johnson, A., Lewis, J., Raff, M., Roberts, K., \& Walter, P. (2015). Molecular Biology of the Cell (6th ed.). New York: Garland Science.

Analog Devices Inc. (2015). Evaluation Board for the 1 Msps 12-bit Impedance Converter Network Analyzer. Analog Devces Inc. Norwood: Analog Devces Inc.

Ando, Y., Mizutani, K., \& Wakatsuki, N. (2014). Electrical Impedance Analysis of Potato Tissues During Drying. Journal of Food Engineering, 121(1), 24 - 31.

Arpaia, P., Clemente, F., \& Romanucci, C. (2008). An Instrument For Prosthesis Oseointegration Assessment By Electrochemical Impedance Spectrum Measurement. Measurement, 41(9), 1040 - 1044.

Azevedo, E. B., Alonso, K. C., \& Cliquet Jr, A. (2016). Body Composition Assessment By Bioelectrical Impedance Analysis And Body Mass Index In Individuals With Chronic Spinal Cord Injury. Journal of Electrical Bioimpedance, 7(1), 2 - 5.

Azzarello, E., Masi, E., \& Mancuso, S. (2012). Electrochemical Impedance Spectroscopy. Dalam Plant Electrophysiology, (pp. 205 - 223). Berlin: Springer.

Bera', T. K., \& Nagaraju, J. (2009). A Study Of Practical Biological Phantoms With Simple Instrumentation For Electrical Impedance Tomography (EIT). IEEE Instrumentation and Measurement Technology Conference, (pp. 511 - 516).

Bera, T. K., Jampana, N., \& Lubineau, G. (2016). A Labview-Based Electrical Bioimpedance Spectroscopic Data Interpreter (LEBISDI) For Biological Tissue Impedance Analysis And Equivalent Circuit Modelling. Journal of Electrical Bioimpedance, 71$), 35$ - 54.

Berra, T. K., \& Nagarraju, J. (2011). Electrical Impedance Spectroscopic Study of Broiler Chicken Tissues Suitable for The Development of Practical Phantoms in Multifrequency EIT. Journal of Electrical Bioimpedance, 2(1), 48 - 63.

Bondarenko, A. S., \& Ragoisha, G. A. (2005). Variable Mott-Schottky plots acquisition by potentiodynamic electrochemical impedance spectroscopy. Journal of Solid State Electrochemistry, 9(12), 845 - 849. 
Bouchaala, D., Kanoun, O., \& Derbel, N. (2015). High Accurate And Wideband Current Excitation For Bioimpedance Health Monitoring Systems. Measurement, 79(1), 339 - 348.

Burg, S. P., \& Burg, E. A. (1965). Ethylene Action And The Ripening Of Fruits Ethylene Influences The Growth And Development Of Plants And Is The Hormone Which Initiates Fruit Ripening. Science, 148(3674), 1190 - 1196.

Chakraborty, S., Das, C., Saha, R., Das, A., Bera, N. K., Chattopadhyay, D., et al. (2015). Investigating The Quasi-Oscillatory Behavior Of Electrical Parameters With The Concentration Of D-Glucose In Its Aqueous Solution At Room Temperature By Employing Impedance Spectroscopy Technique. Journal of Electrical Bioimpedance, 6(1), 10 - 17.

Chowdhury, A., Bera, T. K., Ghoshal, D., \& Chakraborty, B. (2017). Contact Impedance Measurement Using Compound Electrodes From Electrical Impedance Spectroscopy (EIS) Study During Banana Ripening. Journal of Engineering and Apllied Sciences, 12(10), 8924 $-8935$.

Chowdury, A., Bera, T. K., Ghoshal, D., \& Chakraborty, B. (2017). Electrical Impedance Variations In Banana Ripening: An Analytical Study With Electrical Impedance Spectroscopy. Journal of Food Process Engineering, 40(2), e12387.

Damez, J. L., Clerjon, S., Abouelkaram, S., \& Lepetit, J. (2007). Dielectric Behavior Of Beef Meat In The 1-1500 Khz Range: Simulation With The Fricke/Cole-Cole Model. Meat Science, $774), 512-519$.

Damijan, M., Pavselj, N., \& Hart, F. X. (2006). Electric Properties of Tissues. Dalam Wiley Encyclopedia of Biomedical Engineering (Wiley Online Library ed., hal. ebs0403). New York: John Wiley \& Sons, Inc.

Golding, J. B., Shearer, D., Wyllie, S. G., \& McGlasson, W. B. (1998). Application of 1-MCP and Propylene to Identify Ethylene-Dependent Ripening Processes in Mature Banana Fruit. Postharvest Biology and Technology, 14(1), 87 - 98.

Gonzalez, M. C. (2019). Using Bioelectrical Impedance Analysis for Body Composition Assessment: Sorting Out Some Misunderstandings. Journal of Parenteral and Enteral Nutrition, 43(8), $945-953$.

Grossi, M., \& Ricco, B. (2017). Electrical impedance spectroscopy (EIS) for biological analysis and food characterization: a review. Journal of Sensors and Sensor Systems, 6(1), 303 - 325.

Herath, H. W., Bandara, D. C., Selvarajah, S., \& Abeysinghe Banda, D. G. (1998). Effect of PreHarvest Calcium Treatment on Post-Harvest Quality of Pineapple. Tropical Agricultural Research, 10(1), 214 - 224. 
Hopkins, W. G., \& Huner, N. P. (1995). Introduction to Plant Physiology (Vol. 355). New York: Wiley.

Hossain, M. A., Rana, M., Kimura, Y., \& Roslan, H. A. (2014). Changes in Biochemical Characteristics And Activities Of Ripening Associated Enzymes In Mango Fruit During The Storage at Different Temperatures. BioMedical Research International, Article ID 232969.

Islam, M., Wahid, K. A., Dinh, A. V., \& Bhowmik, P. (2015). Model of Dehydration and Assessment of Moisture Content on Onion Using EIS. Journal of Food Science and Technology, 56(6), $2814-2824$.

Kertesz, A., Hlavacova, Z., Vozary, E., \& Staranova, L. (2015). Relationship Between Moisture Content And Electrical Impedance Of Carrot Slices During Drying. International Agrophysics, 29(1), 61 - 66.

Koziol, L., Pitre Jr, J. J., Bull, J. L., Dodde, R. E., Kruger, G., Vollmer, A., et al. (2014). The Feasibility Of Using Compression Bioimpedance Measurements To Quantify Peripheral Edema. Journal of Electrical Bioimpedance, 5(1), 99 - 109.

Lasia, A. (2014). Electrochemical Impedance Spectroscopy and Its Applications. Berlin: Springer. Lelievre, J. M., Latche, A., Jones, B., Bouzayen, M., \& Pech, J. C. (1997). Ethylene and Fruit Ripening. Physiology Plantarum, 101(1), 727 - 739.

Li, X., Wang, T., Pei, L., Zhu, C., \& Xu, B. (2014). A Comparative Study of Sorting Methods for Lithium-ion Batteries. EEE Conference and Expo Transportation Electrification, AsiaPacific, (pp. 556 - 561). Beijing: ITEC Asia-Pacific.

Maryanto, I., Hamidy, A., Keim, A. P., Sihotang, V. L., Lupiyaningdyah, P., Irham, M., et al. (2017, December 30). Ekspedisi Pulau Enggano. Lembaga Ilmu Pengetahuan Indonesia, Lembaga Penelitian Biologi. Jakarta: LIPI Press.

Maxwell, J. C. (1892). A Treatise on Electricity \& Magnetism. London: Oxford University Press.

Ruiz, G. A., Zamora, M. L., \& Felice, C. J. (2014). Impedance Spectroscopy Of Yeast Cells Attached To Gold Electrodes. Journal of Electrical Bioimpedance, 5(1), 40 - 47.

Santos, J., Janeiro, F. M., \& Ramos, P. M. (2014). Impedance Frequency Response Measurements With Multiharmonic Stimulus And Estimation Algorithms In Embedded Systems. Measurement, 48(1), 173 - 182.

Sinaga, E. C., Apri, A., \& Satria, P. U. (2019, October 25). Analisis produksi, pendapatan, dan efisiensi usahatani pisang kepok di Kecamatan Enggano Kabupaten Bengkulu Utara. (Skripsi Sarjana). Kota Bengkulu, Bengkulu, Indonesia: UNIB.

Uygun, Z. O., \& Ertuğrul Uygun, H. D. (2014). A short footnote: Circuit design for faradaic impedimetric sensors and biosensors. Sensors and Actuatators B: Chemical, 202, 448-453. 
Vangelisti, A., Amini, S., Smith, M. P., Brown, J., \& Marsili, E. (2017). Sorting of Food Items With Electrical Impedance Tomography. Dalam Patent Publication WO (hal. Number WO/2019/089038). Geneva: WIPO.

Vasquez-Caicedo, A. L., Schilling, S., Carle, R., \& Neidhart, S. (2007). Effects of Thermal Processing and Fruit Matrix on B-Carotene Stability and Enzyme Inactivation During Transformation of Mangoes Into Puree and Nectar. Food Chemistry, 102(1), 1172 - 1186. Vladikova, D., \& Stoynov, Z. (2004). Secondary Differential Impedance Analysis - A Tool for Recognition of CPE Behavior. Journal of Electroanalitical Chemistry, 572(2), 377 - 387. 